\title{
Partial replacement of wheat flour by pumpkin seed flour in the production of cupcakes filled with carob
}

\author{
Jaqueline Eduarda Rodrigues BATISTA ${ }^{1}$, Lucas Pereira BRAGA ${ }^{1}$, Renata Corrêa de OLIVEIRA ${ }^{1}$, \\ Edson Pablo SILVA ${ }^{2,3 *}$, Clarissa DAMIANI ${ }^{2,3}$
}

\begin{abstract}
Pumpkin seeds are considered waste and its composition has high protein content, being feasible for human consumption, also reducing costs in waste treatment. In this work we provided an alternative to reuse the wastes of pumpkin seed applied in cupcakes formulation as a complementary source to wheat flour. Four formulations with different proportions of pumpkin seed flour were investigated. The effects of partial wheat flour substitution were evaluated using the parameters texture, height, diameter, specific volume, color, proximate composition and scanning electron microscopy. The formulations used in this work consisted of a control, prepared with wheat flour and three provided of $25 \%, 50 \%$ and $75 \%$ of pumpkins seed flour in partial in partial replacement to wheat flour. The incorporation of pumpkin seed flour influenced products significantly $(\mathrm{p}<0.05)$, providing greater texture, cohesion, $\mathrm{pH}$, soluble solids (Brix). According to results, the formulation with 50\% pumpkin seed flour was considered the best proportion due to similarities with the formulation of $100 \%$ wheat flour besides high protein.
\end{abstract}

Keywords: pumpkin seed flour; wheat flour substitution; agroindustrial waste.

Practical Application: Development of new food products with high added value has become a challenge for food industry, since the nutritional quality of the same, will depend on the raw material used. Waste plant materials are promising sources of bioactives that provide nutritional aspects for the human diet and value addition to food products.

\section{Introduction}

The world pumpkin production in 2012 was 25 million tons, and the crop is spread throughout the world, including the production of small farmers and large producers to supply local markets (Food and Agriculture Organization of the United Nations, 2012). The species offers, in addition to pulp, seeds, which can be used in foodstuffs. Pumpkin seed is used in the East in the preparation of breads, cakes and cereals; however, this is not enough to prevent the waste of this material, which can have a beneficial effect on metabolism, physiology and human nutrition since it is rich in fiber, natural source of protein and phytosterols (Moura et al., 2010). Therefore, the inclusion of waste seeds flour in the formulation of food products is an alternative to provide nutritional enrichment and to reduce costs in waste treatment.

In order to provide greater range of products with significant nutritional value, the food industry is using alternative sources plant parts that are usually discharged, such as peels and seeds. These parts are provided by fibers that can improve nutritional aspect for further products (Ambrosio et al., 2006; Tavares et al., 2016). However, for the development of new products based on these co-products, sensory acceptability should be strongly considered. A product easy to be obtained and of easy incorporation of alternative ingredients are cupcakes, which may be filled or not.
The filling most accepted by consumers whether children, adults or older adults is chocolate; however, to have added value and nutritional appeal, carob has been gaining market in recent years. Carob can be used for human consumption, being suggested as a cocoa substitute in the production of chocolate and ice cream, providing a product rich in potassium, copper, iron, magnesium, high in fiber and low in lipids (Medeiros \& Lannes, 2009; Özcan et al., 2007; Sabatini et al., 2011; Yousif \& Alghzawi, 2000).

Therefore, the goal of this work was to evaluate the effects of different proportions of pumpkin seeds flour addition, as a partial replacer to the wheat flour in cupcake formulations filled with carob. The chemical and physical properties of the products were investigated.

\section{Materials and methods}

The preparation of cupcakes filled with carob started with the weighing of ingredients (Table 1), mixed according to the order of ingredients common to all treatments, except for the baking powder, in semi-industrial mixer. After obtaining a homogeneous mixture, wheat flour and / or pumpkin seed flour was added under stirring and, finally, the baking powder was added and manually mixed. The cake batter was placed in paper forms and baked for 40 minutes in a domestic oven, preheated to $180^{\circ} \mathrm{C}$. Cupcakes were cooled at room temperature 
and subsequently filled with 6 grams of carob filling. To prepare the filling, ingredients were weighed as described in Table 2 and cooked until they acquire creamy consistency.

Cupcakes were submitted to the following analyses: color instrumental (CIELAB), base and surface diameter $(\mathrm{cm})$, height $(\mathrm{cm})$, specific volume $\left(\mathrm{mL} \cdot \mathrm{g}^{-1}\right)$, scanning electron microscopy (SEM), texture profile analysis (TPA) using TATXi plus texture analyzer (Stabe Micro Systems, UK), with results expressed in Newton $(\mathrm{N})$ and proximate composition in five replicates.

\subsection{Color parameters}

Color instrumental parameters were determined using colorimeter (Color Quest XE, Reston, Virginia, USA) according to the CIELab system. Results were expressed in $\mathrm{L}^{*}, \mathrm{a}^{*}$ and $\mathrm{b}^{*}$, with $\mathrm{L}$ (how light or dark the sample is), ranging from black (0) to white (100), $\mathrm{a}^{*}$ ranging from green $(-60)$ to red $(60)$ and $\mathrm{b}^{*}$ ranging from blue $(-60)$ to yellow $(+60)$. From the $\mathrm{a}^{*}$ and $\mathrm{b}^{*}$ results, the $\mathrm{C}^{*}$ parameters were calculated (chroma) to indicate sample saturation, that is, to describe brightness and hue $\left(\mathrm{H}^{\circ}\right)$, which expresses the tone of samples, defined by Equations 1 and 2 (Hunterlab, 1998). Color instrumental analyses were performed in five replicates.

$\mathrm{C} *=\left(\mathrm{a}^{* 2}+\mathrm{b}^{* 2}\right)^{1 / 2}$

$\mathrm{H}^{\mathrm{o}}=\tan ^{-1}\left(\mathrm{~b}^{* / \mathrm{a}^{*}}\right)$

\subsection{Scanning electron microscopy (SEM)}

For Scanning electron microscopy of pumpkin seed meal and cupcakes, scanning electron microscope Sputter Coater, SCD 050, Scotia, USA was used. Samples were fixed on aluminum stubs with the aid of double-sided conductive carbon tape and coated with a thin gold film.

Table 1. Formulation of cupcakes filled with carob with different substitution levels of wheat flour (WF) by pumpkin seed flour (PSF).

\begin{tabular}{ccccc}
\hline Ingredient & $\mathrm{T} 1^{\star}$ & $\mathrm{T} 2$ & $\mathrm{~T} 3$ & $\mathrm{~T} 4$ \\
\hline Wheat flour $(\mathrm{g})$ & 116 & 87 & 58 & 29 \\
Pumpkin seed flour (g) & 0 & 29 & 58 & 87 \\
Margarine (g) & 65 & 65 & 65 & 65 \\
Sugar (g) & 100 & 100 & 100 & 100 \\
Salt (g) & 1 & 1 & 1 & 1 \\
Whole fresh egg (unit) & 1 & 1 & 1 & 1 \\
Vanilla essence (mL) & 4 & 4 & 4 & 4 \\
Milk (mL) & 73 & 73 & 73 & 73 \\
Baking powder (g) & 4 & 4 & 4 & 4 \\
\hline
\end{tabular}

*T1 standard cupcake, T2 cupcake with $25 \%$ replacement of WF by PSF, T3 cupcake with $50 \%$ replacement of WF by PSF, T4 cupcake with $75 \%$ replacement of WF by PSF.

Table 2. Filling formulation made with carob of cupcakes with partial substitution of wheat flour (WF) by pumpkin seed flour (PSF).

\begin{tabular}{cc}
\hline Ingredient & Amount \\
\hline Milk $(\mathrm{mL})$ & 300 \\
Sugar $(\mathrm{g})$ & 27 \\
Powder carob $(\mathrm{g})$ & 50 \\
Margarine $(\mathrm{g})$ & 20 \\
\hline
\end{tabular}

\subsection{Proximate composition}

To determine moisture, protein and ash contents of products developed, the methodology suggested by the AOAC (Association of Official Analytical Chemists, 2012) was used. Extraction and determination of total lipids were performed according to the method of Bligh \& Dyer (1959). All analyses were performed in triplicate. The amount of total carbohydrates followed methodology by NEPA (Universidade Estadual de Campinas, 2011), which describes total carbohydrates (Equation 3) by the difference of $100 \mathrm{~g} .100 \mathrm{~g}^{-1}$ with moisture, proteins, lipids and ash. The energy value was given by Equation 4, which relates the energetic capacity of carbohydrates, proteins and lipids to obtain the energy value in Kcal (Association of Official Analytical Chemists, 2012).

Carbohydrates $\left(\mathrm{g} \cdot 100 \mathrm{~g}^{-1}\right)=100($ moisture + proteins + lipids + ash $)$

Energy value $\mathrm{Kcal}=($ Carbohydrates x 4) $+($ proteins x 4$)+($ lipids x 9$)$

\subsection{Texture}

The compression force used was the TPA (was estimated using a texture profile analysis) comprising a double compression cycle that simulates mouth chewing, using $\mathrm{P} / 36$ probe (Larmond, 1997). The parameters recorded were hardness, which represents the deformation necessary for a certain strength, and cohesiveness, representing the amount of energy needed to break the internal interactions of the samples. Furthermore, the elasticity was estimated as the speed at which a deformed material regains its original structure when the compression force is removed. The conditions used for this analysis were in accordance with those used by Kim et al. (2009), i.e., a pretest speed of $60 \mathrm{~mm} / \mathrm{s}$, test speed of $100 \mathrm{~mm} / \mathrm{s}$, post-test speed of $60 \mathrm{~mm} / \mathrm{s}$, and $80 \%$ strain with a cylindrical probe that is $20 \mathrm{~cm}$ in diameter.

\subsection{Specific volume}

The specific volume (EV) was calculated as the relationship between volume and mass, in which volume was determined by the method of millet seeds displacement, according to method described by Silva et al. (1998). The operation was repeated 10 times, and the mean specific volume value for each treatment was measured.

\subsection{Diameter and height}

The diameter and height of cupcakes filled with carob were measured with a digital caliper (Digital Caliper, Messen Danyang, China). The measurements were performed in triplicate.

\subsection{Experimental design and statistical analysis}

The experimental design was completely randomized with four treatments (cupcake without substitution and with substitution of wheat flour by 25, 50 and 75\% pumpkin seed flour) and the averages were compared by the Tukey test at 5\% significance level using SISVAR software, version 5.0. (Ferreira, 2010). 


\section{Results and discussion}

For the determination of the proximate composition of cupcakes, with increasing pumpkin seed flour proportions in formulations, a significant increase in the parameters evaluated was observed, except for the carbohydrate content, which was lower in formulations with the highest pumpkin seed flour concentrations (PSF), substituting wheat flour (Table 3). Lower values were detected by Lebesi \& Tzia (2011), who evaluated the effect of the addition of different dietary fiber and edible cereal bran sources on the baking and sensory characteristics of cupcakes. It was observed that when compared to chocolate cake filled with chocolate, the preparation of cupcakes started, even without substitution of wheat flour by pumpkin seed flour (T1) has higher protein value, smaller amount of lipids and carbohydrates, with consequent lower energy value. Nutritionally, $\mathrm{T} 3$ and T4 were the best treatments, since the lipid content is close to commercially filled cakes with improved relationship between protein and energy content. Lower values for the data of proximal composition were found by Coelho \& Salas Mellado (2015), who developed bread formulations with seed chia.. According to RDC No. 269 (Agência Nacional de Vigilância Sanitária, 2005), the recommended daily protein intake is $50 \mathrm{~g}$ and for food to be considered rich in protein, it must contain $20 \%$ of this total, i.e., the formulations with $50 \%$ and $75 \%$ can be considered rich in proteins.

The results of the texture profile analysis of cupcakes with partial substitution of WF (wheat flour) by PSF (pumpkin seed flour) filled with carob are described in Table 4. For data related to firmness, formulation T4 showed the highest value, probably influenced by the amount of PSF, which may have influenced the firmness by presenting large amount of fibers and low amount of WF, which provided softness to the product. This can be confirmed by the electronic microscopy performed in the samples (Figure 1), where it is observed that according to the percentage of addition of the seed flour, there are modifications in the structure of the product. Firmness is one of the factors that determine the acceptability of food by the consumer and, therefore, its values should not be very high or different from those already known and accepted by consumers (Assis et al., 2009).

Regarding cohesiveness, the values found were lower than those described by Zanqui et al. (2014), which ranged from 0.57 to 0.61 in mini panettone formulations containing golden flaxseed flour contains naturally omega 3 fatty acid in partial substitution of wheat flour. The lower the cohesiveness, the lower the force needed to stretch the food until it is broken (Szczesniak, 2002), therefore, the incorporation of pumpkin seed flour significantly influenced T3 and T4, which may have also influenced the chewiness data of the product, and the lowest results were found in $\mathrm{T} 2$.

Elasticity values were close to those described by Esteller et al. (2006), who obtained values of 0.77-0.93 in the manufacture of breads with reduced caloric content. According to these authors, the addition of proteins can improve elasticity of the final product. The incorporation of proteins in cupcakes may have been due to the addition of pumpkin seed flour and carob used in filling. Therefore, since consumers take into account softness (lower hardness), the product must have lower cohesion and higher elasticity. Accordingly, substitution of up to $50 \%$ of WF by PSF is a good choice if only parameter texture was evaluated.

The coloring results attributed to the formation of crust for the $a^{*}$ parameter were statistically equal $(p<0.05)$ for T2 and T4; while T1 and T3 were statistically different (Table 5 ). Such values may be associated with both the improper incorporation of ingredients into formulations, which may not have been fully homogenized and the non-enzymatic browning during cooking, which may also explain the other values related to color $\left(\mathrm{L}^{\star}, \mathrm{c}^{\star} \mathrm{H}^{\mathrm{o}}, \mathrm{a}^{\star}\right.$ and $\left.\mathrm{b}^{\star}\right)$ of cupcakes. High $\mathrm{a}^{\star}$ values are associated with the reddish color of the "crust". Cakes with too light or too dark crust are associated with failure in processing and usually to high temperatures $\left(180^{\circ}\right.$ to $\left.200{ }^{\circ} \mathrm{C}\right)$ combined with the presence of fermentable sugars, which accelerate Maillard and caramelization reactions (Gutkoski et al., 2011). The values a ranging from 4 to 7.5 were observed for cupcakes. Gutkoski et al. (2011) found $\mathrm{a}^{\star}$ values ranging from 16.2 to 17.3 for English type cake and Paucar-Menacho et al. (2016), found values ranging from 10.5 to 11.5 for cupcakes for children of school age, with partial substitution of wheat flour by soybean. According to

Table 3. Means and standard deviation of the proximate composition of cupcakes with partial substitution of wheat flour (FT) by pumpkin seed flour (PSF) filled with carob.

\begin{tabular}{ccccc}
\hline $\begin{array}{c}\text { Composition } \\
\left.(\text { g.100g })^{-1}\right)\end{array}$ & T1 & T2 & T3 & T4 \\
\hline Moisture & $21 \pm 1^{\mathrm{a}}$ & $21.0 \pm 0.8^{\mathrm{a}}$ & $26 \pm 1^{\mathrm{b}}$ & $25 \pm 1^{\mathrm{ab}}$ \\
Ash & $1.4 \pm 0.1^{\mathrm{a}}$ & $2.0 \pm 0.2^{\mathrm{ab}}$ & $2.0 \pm 0.1^{\mathrm{ab}}$ & $2.0 \pm 0.1^{\mathrm{b}}$ \\
Proteins & $15.0 \pm 0.2^{\mathrm{a}}$ & $17.0 \pm 0.2^{\mathrm{b}}$ & $30.0 \pm 0.1^{\mathrm{c}}$ & $33 \pm 1^{\mathrm{d}}$ \\
Lipids & $11.0 \pm 0.3^{\mathrm{a}}$ & $18.0 \pm 0.7^{\mathrm{b}}$ & $20.0 \pm 0.1^{\mathrm{c}}$ & $23 \pm 1^{\mathrm{d}}$ \\
Carbohydrates & $51 \pm 2^{\mathrm{a}}$ & $43 \pm 2^{\mathrm{b}}$ & $21 \pm 2^{\mathrm{c}}$ & $23 \pm 3^{\mathrm{d}}$ \\
Energy value (Kcal) & $367 \pm 10^{\mathrm{a}}$ & $400 \pm 14^{\mathrm{c}}$ & $387 \pm 8^{\mathrm{b}}$ & $407 \pm 24^{\mathrm{d}}$ \\
\hline
\end{tabular}

Different letters in the same line mean statistical difference $(\mathrm{p}<0.05)$ by the Tukey test.

Table 4. Analysis of firmness and texture parameters of cupcakes produced with partial substitution of wheat flour (WF) by pumpkin seed flour (PSF) filled with carob.

\begin{tabular}{ccccc}
\hline & T1 & T2 & T3 & T4 \\
\hline Firmness (N) & $3.6 \pm 0.3^{\mathrm{a}}$ & $3.0 \pm 0.3^{\mathrm{a}}$ & $4.0 \pm 0.4^{\mathrm{a}}$ & $6.4 \pm 0.7^{\mathrm{b}}$ \\
Cohesiveness & $0.440 \pm 0.004^{\mathrm{a}}$ & $0.43 \pm 0.02^{\mathrm{a}}$ & $0.500 \pm 0.002^{\mathrm{b}}$ & $0.50 \pm 0.01^{\mathrm{ab}}$ \\
Chewiness & $263 \pm 33^{\mathrm{b}}$ & $170 \pm 23^{\mathrm{a}}$ & $270 \pm 17^{\mathrm{b}}$ & $311 \pm 29^{\mathrm{b}}$ \\
Elasticity & $0.74 \pm 0.02^{\mathrm{a}}$ & $1.00 \pm 0.04^{\mathrm{ab}}$ & $1.00 \pm 0.02^{\mathrm{b}}$ & $1.00 \pm 0.06^{\mathrm{b}}$ \\
\hline
\end{tabular}

Different letters in the same line mean statistical difference $(\mathrm{p}<0.05)$ by the Tukey test.

Table 5. Color parameters of the "crust" of cupcakes with partial substitution of wheat flour (WF) by pumpkin seed flour (PSF) filled with carob.

\begin{tabular}{crrrc}
\hline Parameter & \multicolumn{1}{c}{ T1 } & \multicolumn{1}{c}{ T2 } & T3 & T4 \\
\hline $\mathrm{a}^{*}$ & $8 \pm 1^{\mathrm{a}}$ & $4 \pm 1^{\mathrm{b}}$ & $7 \pm 1^{\mathrm{c}}$ & $4.00 \pm 0.6^{\mathrm{b}}$ \\
$\mathrm{b}^{*}$ & $26 \pm 2^{\mathrm{a}}$ & $25 \pm 3^{\mathrm{b}}$ & $24 \pm 1^{\mathrm{b}}$ & $14 \pm 1^{\mathrm{c}}$ \\
$\mathrm{L}^{*}$ & $51 \pm 4^{\mathrm{a}}$ & $49 \pm 6^{\mathrm{a}}$ & $44 \pm 3^{\mathrm{b}}$ & $19 \pm 3^{\mathrm{c}}$ \\
$\mathrm{C}^{*}$ & $28 \pm 2^{\mathrm{a}}$ & $24 \pm 1^{\mathrm{b}}$ & $25 \pm 1^{\mathrm{b}}$ & $15 \pm 1^{\mathrm{c}}$ \\
$\mathrm{h}^{\mathrm{o}}$ & $74 \pm 1^{\mathrm{a}}$ & $80 \pm 2^{\mathrm{b}}$ & $74 \pm 3^{\mathrm{a}}$ & $72 \pm 3^{\mathrm{c}}$ \\
\hline
\end{tabular}

Different letters in the same line mean statistical difference $(\mathrm{p}<0.05)$ by the Tukey test. 

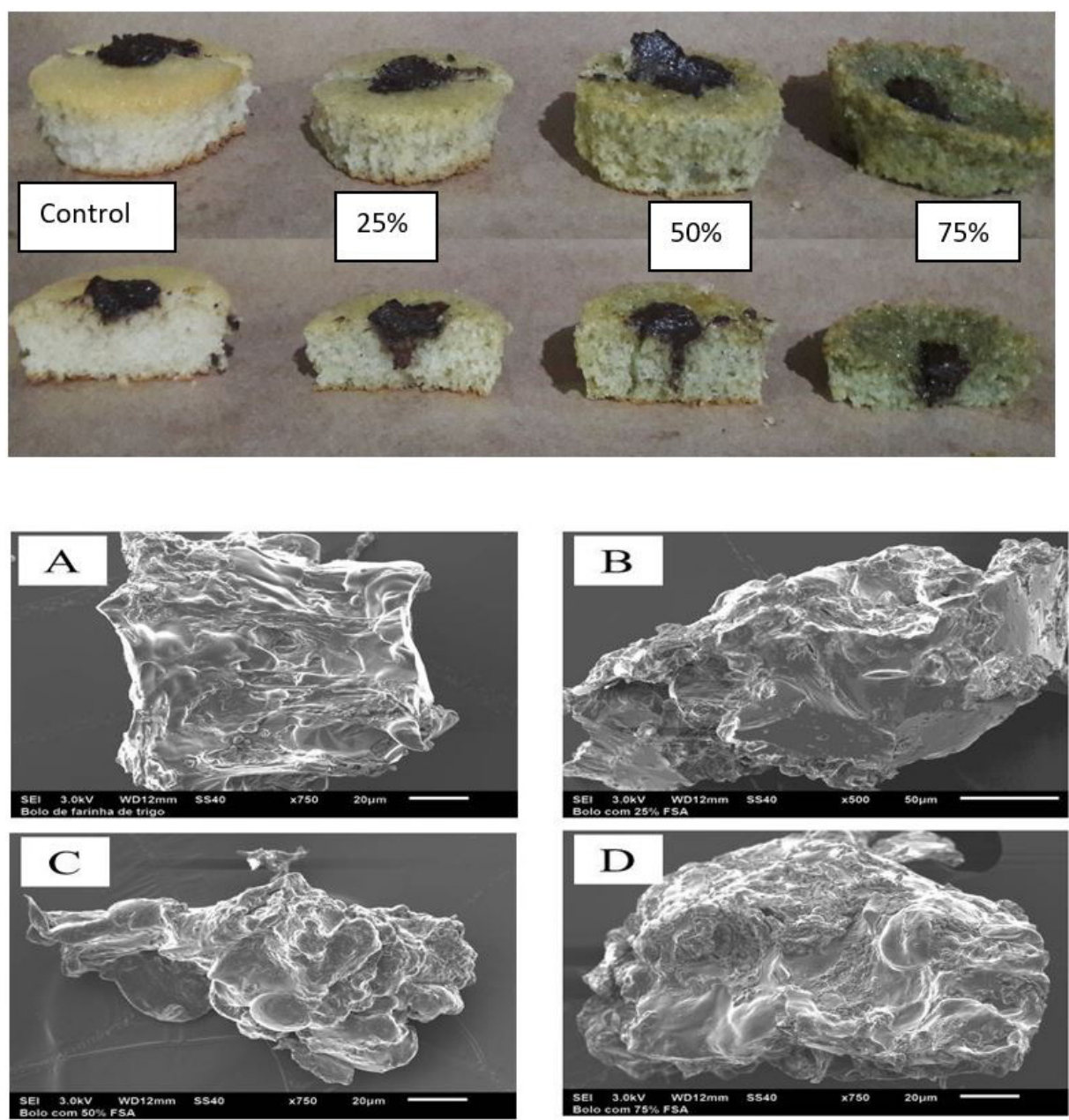

Figure 1. Images of cupcakes in the developed formulations (0\%, 25\%,50\% and 75\%). Scanning electron microscopy: (A) of wheat flour cupcake with 750x magnification; (B) cupcake with $25 \%$ pumpkin seed flour with 500x magnification; (C) cupcake with 50\% pumpkin seed flour with 750x magnification; (D) cupcake with 75\% pumpkin seed meal with 750x magnification.

Esteller \& Lannes (2005), some variations in $\mathrm{a}^{\star}$ and $\mathrm{b}^{\star}$ values may be also related to the degree of aeration and changes in light incidence on the material surface. Similar result was found by Bitencourt et al. (2014), who analyzed cakes prepared with PSF and Perez \& Germani (2007), who worked with crackers using eggplant flour. Thus, according to values observed for parameters $\mathrm{a}^{\star}, \mathrm{b}^{\star}$, lightness $(\mathrm{L})$ and chroma $\left(\mathrm{C}^{\star}\right)$, the substitution of $50 \%$ wheat flour by pumpkin seed flour is feasible, since for all parameters analyzed, values were close to $\mathrm{T} 1$, even though $\mathrm{T} 3$ had $\mathrm{L}^{*}$ and $\mathrm{C}$ values statistically different from $\mathrm{T} 1$.

Although significant differences among formulations in relation to the pattern were not observed, in the diameter and height analysis (Table 6), it was found that the incorporation of PSF significantly influenced the size of cupcakes, since the lowest values for specific volume were detected in formulations in which the wheat fraction was lower. Such behavior may be related to the power of expansion and wheat growth in relation to the application of heat and less formation of gluten networks in formulations with higher percentages of pumpkin seed flour. This result is corroborated by the greater texture found in T4 and by the electron microscopy (Figure 1), in which greater
Table 6. Diameter, height and specific volume of cupcakes with partial substitution of wheat flour (WF) by pumpkin seed flour (PSF) filled with carob.

\begin{tabular}{lcccc}
\hline \multicolumn{1}{c}{ Parameters $(\mathrm{mm})$} & $\mathrm{T} 1$ & $\mathrm{~T} 2$ & T3 & T4 \\
\hline Base diameter & $52 \pm 2^{\mathrm{a}}$ & $49 \pm 2.0^{\mathrm{a}}$ & $50.0 \pm 0.6^{\mathrm{a}}$ & $50 \pm 1^{\mathrm{a}}$ \\
Surface diameter & $58 \pm 1^{\mathrm{a}}$ & $58 \pm 2^{\mathrm{a}}$ & $59 \pm 2^{\mathrm{a}}$ & $54 \pm 2^{\mathrm{a}}$ \\
Height & $28 \pm 0.5^{\mathrm{a}}$ & $25 \pm 1^{\mathrm{a}}$ & $28.0 \pm 0.7^{\mathrm{a}}$ & $25 \pm 1^{\mathrm{a}}$ \\
Specific volume $\left(\mathrm{mL} \cdot \mathrm{g}^{-1}\right)$ & $2.0 \pm 0.1^{\mathrm{a}}$ & $2.0 \pm 0.2^{\mathrm{a}}$ & $2.0 \pm 0.1^{\mathrm{b}}$ & $1.0 \pm 0.2^{\mathrm{c}}$ \\
\hline
\end{tabular}

Different letters in the same line mean statistical difference $(\mathrm{p}<0.05)$ by the Tukey test.

compression of sample with the highest percentage of pumpkin seed meal can be observed. Bick et al. (2014) observed similar values when studying cookies developed with quinoa flour and attributed the difference in growth to the low gluten content and strength of the mass, which forms a brittle film instead of a viscoelastic network. It could be considered that the addition of pumpkin seed flour reduces the viscoelastic network created by gluten due to the absence of this protein in this pseudocereal.

In the electron microscopy analysis realized in the cupcake formulations (Figure 1), it wasn't observed the gluten networks formation, corroborating with the results founded for texture 
and specific volume of cupcakes developed. Studying the effect of the addition of rice flour in cupcakes, Park et al. (2012), detected by means of the electron microscopy analysis, that the percentage of addition of the flour, influenced significantly the texture, being evidenced by the images.

\section{Conclusion}

In this work, four formulations of cupcake using pumpkin seed flour in partial replacement to wheat flour were investigated $(0 \%, 25 \%, 50 \%$ and $75 \%)$. The use of the flour obtained from the pumpkin seed in the formulation of cupcakes up to the $50 \%$ level proved to be a viable alternative for the use of this coproduct. Contributing to a protein increase and without substantial changes in the original characteristics of the product.

\section{References}

Agência Nacional de Vigilância Sanitária - ANVISA. (2005, September 23). Resolução $R D C n^{\circ} 269$, de 22 de setembro de 2005. O regulamento técnico sobre a ingestão diária recomendada (IDR) de proteína, vitaminas e minerais. Diário Oficial [da] República Federativa do Brasil. Retrieved from http://portal.anvisa.gov.br/wps/wcm/connect/188497004745781 1857dd53fbc4c6735/RDC_269_2005.pdf?MOD=AJPERES

Ambrosio, C. L. B., Campos, F. A. C. S., \& Faro, Z. P. (2006). Carotenoids as an alternative against vitamin A deficiency. Revista de Nutrição, 19(2), 233-243.

Assis, L. M., Zavareze, E. R., Radünz, A. L., Dias, Á. R. G., Gutkoski, L. C., \& Elias, M. C. (2009). Nutritional properties, technological and sensory biscuits with wheat flour substitute for oatmeal or rice flour parboiled. Alimentos e Nutrição, Araraquara, 20(1), 15-24.

Association of Official Analytical Chemists - AOAC. (2012). Official Methods of Analysis of AOAC International. 19th ed. Gaithersburg: AOAC.

Bick, M. A., Fogaça, A. O., \& Storck, C. R. (2014). Biscoitos com diferentes concentrações de farinha de quinoa em substituição parcial à farinha de trigo. Brazilian Journal of Food Technology, 17(2), 121-129. http:// dx.doi.org/10.1590/bjft.2014.015.

Bitencourt, C., Dutra, F. L. G., Pinto, V. Z., Helbig, E., \& Borges, L. R. (2014). Elaboração de bolos enriquecidos com semente de abóbora: avaliação química, física e sensorial. Boletim do Centro de Pesquisa e Processamento de Alimentos, 32(1), 19-32.

Bligh, E. G., \& Dyer, W. J. (1959). A rapid method of total lipid extraction and purification. Canadian Journal of Biochemistry and Physiology, 37(8), 911-917. PMid:13671378. http://dx.doi.org/10.1139/o59-099.

Coelho, M. S., \& Salas-Mellado, M. (2015). Effects of substituting chia (Salvia hispanica L.) flour or seeds for wheat flour on the quality of the bread. Lebensmittel-Wissenschaft + Technologie, 60(2), 729-736. http:// dx.doi.org/10.1016/j.lwt.2014.10.033.

Esteller, M. S., Lima, A. C. O., \& Lannes, S. C. S. (2006). Color measurement in hamburger buns with fat and sugar replacers. Lebensmittel-Wissenschaft + Technologie, 39(2), 184-187.http://dx.doi.org/10.1016/j.lwt.2004.12.012.

Esteller, M. S., \& Lannes, S. C. S. (2005). Additional parameters for setting of identity and quality bakery products. Food Science and Technology, 25(4), 802-806. http://dx.doi.org/10.1590/S0101-20612005000400028.

Ferreira, D. F. (2010). Sisvar: variance analysis system. Version 5.3. Lavras: UFLA.

Food and Agriculture Organization of the United Nations - FAO. Statistics Division. (2012). Pumpkins, squash \& gourds statistic 2012. Rome: FAO. Retrieved from http://faostat3.fao.org/

Gutkoski, L. C., Durigon, A., Mazzutti, S., Cezare, K., \& Colla, L. M. (2011). Influência do tipo de farinha de trigo na elaboração de bolo tipo inglês. Brazilian Journal of Food Technology, 14(4), 275-282. http://dx.doi. org/10.4260/BJFT2011140400033.
Hunterlab. (1998). User's manual with universal software versions 3.5 (428 p.). Reston: Hunterlab.

Kim, E. H.-J., Corrigan, V. K., Hedderley, D. I., Motoi, L., Wilson, A. J., \& Morgenstern, M. P. (2009). Predicting the sensory texture of cereal snack bars using instrumental measurements. Journal of Texture Studies, 40(4), 457-481. http://dx.doi.org/10.1111/j.1745-4603.2009.00192.x.

Larmond, E. (1997). Laboratory methods for sensory evaluation of food (73 p.). Ottawa: Agriculture Canada.

Lebesi, D. M., \& Tzia, C. (2011). Effect of the addition of different dietary fiber and edible cereal Bran sources on the baking and sensory characteristics of cupcakes. Food and Bioprocess Technology, 4(5), 710-722. http:// dx.doi.org/10.1007/s11947-009-0181-3.

Medeiros, M. L., \& Lannes, S. C. S. (2009). Avaliação química de substitutos de cacau e estudo sensorial de achocolatados formulados. Food Science and Technology, 29(2), 247-253. http://dx.doi.org/10.1590/S010120612009000200002.

Moura, F. A., Spier, F., Zavareze, E. R., Dias, A. R. G., \& Elias, M. C. (2010). Cookies type "cookie" made with different pumpkin (Curcubita máxima) seed fractions. Alimentos e Nutrição, 21(4), 579-585.

Özcan, M. M., Arslan, D., \& Gökçalik, H. (2007). Some compositional properties and mineral contents of carob (Ceratonia siliqua) fruit, flour and syrup. International Journal of Food Sciences and Nutrition, 58(8), 652-658. PMid:17852490. http://dx.doi.org/10.1080/09637480701395549.

Park, S. J., Ha, K. Y., \& Shin, M. (2012). Properties and qualities of rice flours and gluten-free cupcakes made with higher-yield rice varieties in Korea. Food Science and Biotechnology, 21(2), 365-372. http://dx.doi. org/10.1007/s10068-012-0048-7.

Paucar-Menacho, M. L., Salvador-Reyes, R., Guillén-Sánchez, J., \& MoriArismendi, S. (2016). Effect of partial substitution of wheat flour by soybean meal in technological and sensory characteristics of cupcakes for children of school age. Scientia Agropecuaria, 7(2), 121-132. http:// dx.doi.org/10.17268/sci.agropecu.2016.02.05.

Perez, P. M. P., \& Germani, R. (2007). Elaboração de biscoitos tipo salgado, com alto teor de fibra alimentar, utilizando farinha de berinjela (Solanum melongena, L.). Ciência e Tecnologia de Alimentos, 27(1), 186-192. http:// dx.doi.org/10.1590/S0101-20612007000100033.

Sabatini, D. R., Silva, K. M., Picinin, M. E., Santo, V. R. D., Souza, G. B., \& Pereira, C. A. M. (2011). Composição centesimal e mineral da alfarroba em pó e sua utilização na elaboração e aceitabilidade em sorvete. Alimentos e Nutrição, Araraquara, 22(1), 129-136.

Silva, M. R., Silva, M. A. A. P., \& Chang, Y. K. (1998). Use of jatobá flour (Hymenaea stigonocarpa Mart.) In the development of type of cookies and evaluation of acceptance by univariate and multivariate affective sensory tests. Food Science and Technology, 18(1), 25-34. http://dx.doi. org/10.1590/S0101-20611998000100007.

Szczesniak, A. S. (2002). Texture is a sensory property. Food Quality and Preference, 13(4), 215-225. http://dx.doi.org/10.1016/S09503293(01)00039-8.

Tavares, B. O., Silva, E. P., Silva, V. S. N., Soares, M. S. Jr., Ida, E. I., \& Damiani, C. (2016). Stability of gluten free sweet biscuit elaborated with rice bran, broken rice and okara. Food Science and Technology, 36(2), 296-303. http://dx.doi.org/10.1590/1678-457X.0083.

Universidade Estadual de Campinas - UNICAMP. (2011). TACO: Tabela Brasileira de Composição de Alimentos. 4th ed. Campinas: UNICAMP.

Yousif, A. K., \& Alghzawi, H. M. (2000). Processing and characterization of carob powder. Food Chemistry, 69(3), 283-287.http://dx.doi.org/10.1016/ S0308-8146(99)00265-4.

Zanqui, A. B., Bastiani, D., de Souza, A. H. P., Marques, D. R., Gohara, A. K., Matsushita, M., \& Monteiro, A. R. G. (2014). Mini panettone preparation containing Omega-3 for replacement partial wheat flour by flour golden flaxseed (Linum usitattissimum L.). Revista Virtual de Química, 6(4), 968-976. 